DOI: $10.1590 /$ permusi2015a3117

\title{
Agência dos objetos sonoros
}

Rosângela Pereira de Tugny (Escola de Música da UFMG, Belo Horizonte, MG) tugny@ufmg.br

Resumo: Este texto busca se aproximar do discurso de especialistas ameríndios sobre a origem não autoral de suas músicas, onde a escuta ocupa a função de produção. Busca também compreender as limitações dos artistas ocidentais quando tentam colaborar com as formas de trabalho acústico operantes entre estes coletivos. À luz de reflexões de Bruno Latour e Jacques Rancière em torno de temas relacionados às políticas da estética, às noções de "produção" e às fissuras construídas pelas sociedades modernas entre noções de natureza e cultura, é revisitado o percurso singular do compositor francês Pierre Boulez, como forma de problematizar um encontro da produção artística musical dos círculos de compositores de salas de concerto com as cosmossonologias ameríndias.

Palavras-chave: estéticas ameríndias; criação musical; políticas da estética.

\section{Sonorous Objects Agency}

Abstract: This text aims at approaching the speeches of Amerindian specialists on nonauthorial origin of their music - in which the activity of listening occupies the function of production - and also to understand the limitations of Western artists whenever they try to collaborate with the forms of acoustic work which operate in these collective realities. Under the light of reflections made by Bruno Latour and Jacques Rancière on themes related to the politics of aesthetics, the notions of "production" and the breaches built by modern societies between nature and culture, the present study revisits the singular path of French composer Pierre Boulez as a way of dealing with the encounter between the artistic musical production of the circle of composer who write for concert halls with Amerindian cosmosonology.

Keywords: Amerindian aesthetics; musical creation; politics of aesthetics.

\section{Preâmbulo}

Em 2008 fui convidada a participar de um projeto de concepção e realização de uma ópera sobre a "Amazônia" - finalmente, e sem a minha participação, estreada como "Teatro musical" - na Bienal da Ópera de Munique em Maio de 2010. A sua idealização e produção se dividia entre a direção desta Bienal, a Petrobrás, o Goethe Institut de São Paulo e o Museu ZKM de Arte e Tecnologia de Karlsruhe. Antes mesmo desse convite, seus produtores já haviam escolhido os compositores, diretores de cena e artistas plásticos que comporiam a equipe de criação. Esperava-se de mim alguma consultoria sobre a "música indígena" que pudesse contribuir com a concepção da ópera. Em um dos seus primeiros textos, o projeto expunha o desejo de colocar em perspectiva duas visões de mundo confrontadas atualmente na Amazônia: a da tecnociência e a dos indígenas, ambas atualmente produtoras de informação sobre a floresta. $O$ espaço de produção desta ópera se transformaria em um espaço comum, onde a virtualidade produtiva do xamã se encontraria com a do filósofo ou do cientista ocidental. 
No entanto, bem além deste sonho de partilha de um espaço comum, e desta promoção científico-filosófica concedida ao xamã, o que me parecia mais importante encenar neste projeto de ópera era o drama da irreparável assimetria que envolve o universo dos homens da floresta com respeito ao universo dos criadores da ópera reunidos em Munique. Em primeiro lugar porque os poderes que um destes grupos tem para agir sobre o espaço de vida do outro são, de entrada de jogo, sem nenhuma possibilidade de reciprocidade. A tecnociência possui efeitos gigantescos sobre a vida dos indígenas da floresta e não o contrário. Em seguida porque estão aí duas modalidades disparates de fazer uso do conhecimento e da tecnologia da sociedade dos humanos com respeito às demais. Se, seguindo o pensamento de CLASTRES (1974), as técnicas desenvolvidas pelas sociedades ocidentais para obter os recursos vitais em um ambiente qualquer funcionam por atos de dominação absoluta de tudo aquilo que em nossa partição moderna classificamos como pertencendo ao domínio da natureza, entre os povos indígenas, o que se passa é o contrário: lidam moderadamente com os recursos, apenas os necessários, para que possam justamente empreender o seu verdadeiro trabalho: o trabalho estético.

Não pretendia colaborar como um agente facilitador na captação de sons, de instrumentos, e mesmo - quem sabe? - de alguns cantores indígenas escolhidos na floresta para comporem o cenário da produção de um evento artístico sobre eles e sua floresta. Mas esta recusa ainda não me parecia suficiente: teria sido necessário ir mais além e inverter desde o início do jogo todos os agentes e os espaços do evento. Deitar abaixo os espaços fechados de produção artística criados pelo mundo ocidental, refletir sobre os sentidos da escuta antes de levar sensores para captar os sons da floresta - como expunha em seu desejo o Diretor do ZKM, um dos principais idealizadores do projeto. Seria necessário repensar estes "parques humanos" que nas palavras do filósofo alemão SLOTERDIJK (2000) definem as repartições da vida urbana em esferas domesticadas: do trabalho, da atividade artística, do lazer ${ }^{1}$.

\section{Uma estético-ecologia-política indígena}

Entre as populações ameríndias, o que vemos como danças, músicas, rituais, máscaras, pinturas corporais, grafismos, enfim, como produções que tenderíamos a pensar como formas artísticas, são apenas as expressões mais perceptíveis de um modo de ser que é o da maioria deles, e que os etnólogos vêm tratando como o xamanismo. Este modo de ser, intensamente relacional, funciona como uma estético-ecologia-política indígena, fundada numa ontologia que pressupõe a copresença densa de corpos singulares, visíveis, invisíveis, móveis e imóveis em seus espaços de vida. Em outros termos, junto aos povos indígenas, aquilo que gostaríamos de denominar fatos "artísticos" forma um modo de ser e gerenciar relações carregadas de afetos entre distintas sociedades corporais que coabitam os seus espaços. Estas relações existem a partir de suas qualidades sensíveis plenas. Não existe, nesta rede de relações, um uso utilitário de coisas, de 
recursos, de alimentos. Em cada intervenção há uma medida, a observação atenta de um acordo, o controle de uma contrapartida. A medida dos atos entre os ameríndios é geralmente objeto de um intenso trabalho, de uma rigorosa etiqueta. O cuidado com o excesso, com o perigo do extermínio, e tudo o que diz respeito à intensidade dos gestos, se revela talvez como o centro das mais fortes atenções no coração da Amazônia e outras regiões habitadas por povos ameríndios. Todo o trabalho ritual e a carga atualizada de seus mitos estão a relembrar a estes povos esta possibilidade. Um mundo demasiado humano, sem alteridade: é nisto que reside o horror, o caos para estes povos. ${ }^{2}$ Os atos estéticos entre os povos ameríndios servem então incessantemente a controlar a medida de suas intervenções sobre outros povos que partilham com eles o seu espaço, a regular as trocas que realizam com diferentes coletivos.

Se parecíamos todos os criadores desta Ópera concordar com os trágicos problemas que a Amazônia desvela no cenário cosmopolítico, havia um problema pendente neste grupo, o da sua criação, ou seja, a criação de uma obra artística do homem ocidental, com todos os investimentos que isto significa. $E$ este complexo fato artístico-econômico, a Ópera Ocidental dizia exatamente respeito a esta ruptura de vínculos com respeito aos vários coletivos que foram emudecidos pelas sociedades urbanas. Não, desta vez não: os coletivos da floresta não poderiam servir de matéria - amorfa e silenciosa - para que os artistas do velho mundo encenassem o seu temor diante de seu anunciado desaparecimento.

\section{Escuta versus criação}

O que esta impossibilidade de colaboração me proporcionou foi um desejo maior de confrontar a noção de criação artística humanocêntrica, ocidental, onde o humano age sobre os materiais e a cultura age sobre a natureza, a uma noção de escuta, a ameríndia, que se situa em outra região de sociabilidade, onde os humanos não são os únicos agentes que modificam o espaço em que vivem, onde a fonte da subjetividade não está no sujeito, mas fora dele. Ainda que tenhamos assistido desde os anos 50 a uma série de discursos sobre a crise da subjetividade dos artistas pertencentes a determinados regimes de validação estética dos centros urbanos - cujas obras se apresentam em exposições, galerias ou salas de concertos - raros são os que passaram a abdicar da noção mesma de autoria e de obra artística, em função de algum projeto de diluição gestual coletiva. Em contraposição, releva-se de praticamente todas as etnografias, que os povos ameríndios remetem a aquisição dos seus repertórios gráficos e musicais a encontros realizados com diferentes agentes que fazem parte de seus coletivos, aos quais estão ligados (SEEGER 1987, VIVEIROS DE CASTRO 2002, LAGROU 2007). Suas músicas são coisas objetivas, são portanto adquiridas, capturadas como outras substâncias de troca ou de guerras. Em outras palavras, são coisas do mundo, estão aí, materialmente, e não são a expressão, impalpável, do desejo e da subjetividade humana. 
É em torno deste discurso ameríndio que afirma uma origem não autoral das suas músicas e das suas implicações sobre um dos mais importantes divisores de nossas esferas de percepção dos espaços e das coletividades - opondo em dois extremos um polo denominado natureza e outro denominado cultura - que proponho esta reflexão. O que seria uma música objetiva, não processada pela subjetividade artística humana? O que seria uma música onde natureza e cultura não se opõem como campos excludentes? O que dizem os ameríndios quando dizem que suas músicas lhes foram dadas por coletivos-morcegos, gaviões, abelhas, papagaios, enfim, por uma série de coletivos que nos acostumamos a conter como inexpressivos, não dotados de linguagem, sob um véu chamado "Natureza"? Como refletir sobre este tema de outra forma que não seja a de velar sob o cômodo discurso de um "relativismo cultural", uma crença minha na crença dos indígenas? Como cercar este problema sem apenas interpretar esta enunciação nativa, fazendo-a dizer outra coisa, sem lhe conferir o tratamento objetivo que reclamam os indígenas?

Na minha condição de pesquisadora de uma sociedade moderna e ocidental, este problema consiste em compreender a natureza do vínculo que podem ter os cantores indígenas com estes coletivos que lhes ensinam as suas músicas, diferentemente dos meus vínculos, pois pertenço a uma sociedade onde objetos e seres não-humanos não possuem agência. Mas antes disto, um esclarecimento sobre os termos "moderno", "ocidental" e sobre a forma como venho pensando o problema da autoria como sendo essencialmente relacionado ao divisor "Natureza" X Cultura", com o qual vimos construindo nossos discursos sobre as relações entre pessoas, pessoas e coisas, e entre pessoas e coisas da natureza.

\section{A "multidão daquilo que faz agir"}

Bruno LATOUR, professor na École Nationale Supérieure des Mines em Paris, filósofo, epistemólogo, historiador das ciências, se definindo ele mesmo como um "sujeito híbrido" vem, desde seu livro-manifesto Jamais fomos modernos (2000 [1991]), tratando de esmiuçar os mecanismos - sociais, políticos, científicos, religiosos - criados pela contenção em esferas separadas daquilo que os modernos denominam como "natureza" e "cultura". Latour poderia assim ser considerado um antropólogo da modernidade - ou um antropólogo da ciência ou ainda antropólogo da natureza, já que o que busca é pensar este divisor. Latour propõe que

\footnotetext{
"O etnólogo do nosso mundo deve colocar-se no ponto comum, onde se dividem os papéis, as ações, as competências que irão enfim permitir definir certa entidade como animal ou material, uma outra como sujeito de direito, outra como dotada de consciência, ou maquinal e outra como inconsciente ou incapaz. Ele deve até mesmo comparar as formas sempre diferentes de definir ou não a matéria, o direito, a consciência, a alma dos animais sem partir da metafísica moderna." (LATOUR, 2005, p.21)
}

Como um historiador das ciências, LATOUR busca retraçar os momentos de invenção deste "mundo moderno", a partir dos trabalhos realizados por Robert 325 
Boyle e Thomas Hobbes no século XVII. Boyle construiu um laboratório em sua casa e fez experiências com a câmara de vácuo e a máquina de ar. Hobbes propôs em Leviatã a teoria de um estado, um contrato social que estivesse acima dos indivíduos. Segundo LATOUR este é o momento em que os divisores das esferas Natureza e Cultura passaram posteriormente a ser domínio de diferentes ciências:

\begin{abstract}
"Se formos até o fim da simetria entre as duas invenções de nossos dois autores [Boyle e Hobbes], compreenderemos que Boyle não criou simplesmente um discurso científico enquanto Hobbes fazia o mesmo para a política; Boyle criou um discurso político de onde a política deve estar excluída, enquanto que Hobbes imaginou uma política científica da qual a ciência experimental deve estar excluída. Em outras palavras, eles inventaram nosso mundo moderno, um mundo no qual a representação das coisas através do laboratório encontra-se para sempre dissociada da representação dos cidadãos através do contrato social. (...) Os dois ramos do governo elaborados por Boyle e Hobbes só possuem autoridade quando claramente separados (...) Cabe à ciência a representação dos nãohumanos, mas the é proibida qualquer possibilidade de apelo à política; cabe à política a representação dos cidadãos, mas lhe é proibida qualquer relação com os não-humanos produzidos e mobilizados pela ciência e tecnologia." (LATOUR, 2005, p. 33 e 34)
\end{abstract}

É assim que, em um texto posterior, Bruno LATOUR se consagrou a uma discussão que denominou Reflexão sobre o culto moderno dos deuses fe(i)tiches (2002 [1996]). A expressão forjada por ele na língua francesa como faitiche buscava associar na mesma palavra os termos "fato", e "fetiche" associando etimologicamente dois trabalhos de fabricação: o do laboratório científico onde se enclausura o estabelecimento dos fatos, e os fetiches. Ambos são termos que dizem respeito a ações, embora sujeitos à "obsessiva distinção": os fatos são racionais, os fetiches irracionais. A associação de LATOUR deve permitir desviar a atenção em direção "daquilo que nos faz agir", tornando, nas suas palavras, "as distinções entre as figuras obsoletas do objeto e do sujeito, do fabricante e do fabricado, do ator e do "agido" cada dia mais improváveis". É assim que LATOUR comenta que as "noções vagas de 'Ocidental' e 'Moderno'" podem ser definidas "muito simplesmente" da seguinte forma:

"[o ocidental é] aquele que quebrou os fetiches, vê nos Outros, seres estranhamente vinculados (presos), monstros perdidos nas suas crenças..." e: "Incapaz de ver em si os vínculos que o fazem agir, aquele que se crê, por este único fato, Ocidental, imagina que os Outros não o são, e que eles são, consequentemente Outros, embora apenas se diferenciem por aquilo que justamente os vincula." (LATOUR, 2000, p. 7)

O que persegue LATOUR é então o desejo de criar uma modalidade de ciências sociais que, mais do que se interessar pelos indivíduos e sociedades, se interesse à "multidão daquilo que faz agir". Se no primeiro caso tratava-se de percorrer o espaço que liga os sujeitos às estruturas sociais, no segundo atravessar-se-ia espaços que "não encontram nem o indivíduo e nem a sociedade, pois tudo o que é posto em movimento depende da natureza dos 
vínculos e da capacidade que eles podem ter de produzir sujeitos que são a eles ligados" (LATOUR, 2000, p. 3).

\title{
5. "Ouvir como falantes aqueles que apenas eram entendidos como animais ruidosos"
}

Ainda que com reflexões que pareçam se voltar exclusivamente para o mundo artístico ocidental, um outro filósofo, Jacques RANCIÈRE, em Malaise dans l'esthétique (2004), apresenta questões que se aproximam desta antropologia das "multidões daquilo que faz agir" de Bruno LATOUR. Suas reflexões prefiguram um certo pensamento sobre as formas artísticas ocidentais que nos ajudariam ao mesmo tempo cotejar algo que aqui chamaria de uma cosmopolítica-ecologiaestética indígena e pensar o problema que venho colocando em torno da autoria ou da noção de criação artística. Este filósofo distingue três regimes de identificação da arte ocidental, de seu edifício e de seus modos de inteligibilidade: o regime ético das imagens, o regime representativo da arte e o regime estético da arte. O "regime estético da arte" é aquele que parece mais interessá-lo, bem como às reflexões que tento formular aqui. Segundo RANCIÈRE, no regime estético da arte, as coisas da arte pertencem a um "sensorium específico, que "se realiza dentro de uma experiência específica suspendendo as conexões ordinárias, não apenas entre aparência e realidade, mas também entre forma e matéria, atividade e passividade, entendimento e sensibilidade". (...) Pertencer a um sensorium específico, significa para RANCIĖRE se opor duas vezes a um estatuto representativo: não possuir uma aparência que se refira a uma realidade e "não ser uma forma ativa imposta a uma matéria passiva". Este sensorium se configuraria como uma suspensão que fundaria uma "nova arte de viver", uma "nova forma de vida em comum", "uma certa política". Estar neste regime estético seria "pertencer a um sensorium diferente daquele do poder, da dominação":

\begin{abstract}
"O poder da «forma» sobre a «matéria» é o poder do Estado sobre as massas, é o poder da categoria da inteligência sobre a categoria da sensação, dos homens da cultura sobre os homens da natureza. Se o «livre-jogo» [Friedrich Schiller] e a "aparência» estética fundam uma nova comunidade, é porque eles são a refutação sensível desta oposição entre a forma inteligente e a matéria sensível que consiste justamente na diferença entre duas humanidades". (RANCIĖRE 2004, p.46)
\end{abstract}

É assim que RANCIĖRE chega a definir uma política própria a este "regime estético da arte", uma política que o distancia do poder e que designa um modo de ser e partilhar a experiência no espaço:

\footnotetext{
"Com efeito, a política [a política deste regime estético da arte] não é o exercício do poder e a luta pelo poder. Ela é a configuração de um espaço específico, o recorte de uma esfera particular de experiência, de objetos colocados como comuns ligados a uma decisão comum, de sujeitos reconhecidos capazes de designar estes objetos e de argumentar a seu respeito." [...]
} 
"[Esta] política consiste em reconfigurar a partilha do sensível que define aquilo que é comum em uma comunidade, a introduzir aí sujeitos e objetos novos, a tornar visível aquilo que não era e a fazer ouvir como falantes aqueles que apenas eram entendidos como animais ruidosos. Este trabalho de criação da dissensão constitui então uma estética da política, o que não teria nada a ver com as formas de mise en scène do poder e da mobilização das massas, designadas por Benjamim como a "estetização da política»".

(RANCIÈRE, 2004, p.38)

A experiência de certos regimes estéticos da arte consiste numa resistência radical à necessidade capitalista de suprimir a ociosidade, o livre-jogo e a estética do cotidiano em proveito da produtividade. Tratar-se-ia, para RANCIĖRE, de uma resistência própria de uma comunidade autônoma:

"...uma comunidade livre, autônoma é uma comunidade cuja experiência vivida não se parte em esferas separadas, ela não conhece separação entre a vida cotidiana, a arte, a política ou a religião". (RANCIĖRE, 2004, p.52)

Mas antecipemos o cenário diante do qual nos conduzirá RANCIÈRE: encontramo-nos novamente na linha de tensão, a reanimar o paradoxo que a promessa política de uma experiência estética deste tipo expõe. Por um lado uma "política" própria ao regime estético da arte que propõe anular o suspense estético e transformá-lo em forma de vida - como as Artes decorativas, os ensaios dos engenheiros e arquitetos do Werkbund ou do Bauhaus, enfim, conhecemos algumas destas tentativas. Por outro, "a política da forma resistente" preferida de Adorno, ela também bem própria ao regime estético da arte, em que "a forma artística afirma sua politicidade ao se afastar de qualquer forma de intervenção sobre e no mundo prosaico" (idem, p.54). Um paradoxo que no cenário musical seria a grosso modo representado pelas figuras de Kurt Weil (anulando o suspense estético e transformando-o em forma de vida) e Schoenberg (afirmando a política da forma resistente). Uma estratégia de politicidade que teria sido "interiorizada por toda uma tradição vanguardista", nos diz o autor.

Duas políticas, duas estratégias próprias ao regime estético da arte que se articulam em um limite, que se animam de uma tensão. É diante desta zona-limite que RANCIĖRE evoca uma "estética liotardiana do sublime", uma estética que trata da experiência do homem ocidental diante da "potência de uma alteridade irremediável":

\begin{abstract}
"A heterogeneidade sensível da obra não é mais garantia da promessa de emancipação. Ao contrário, ela passa a invalidar qualquer promessa deste tipo, testemunhando uma irremediável dependência do espírito com respeito ao Outro que o habita. $O$ enigma da obra que antes inscrevia a contradição de um mundo, se torna puro testemunho da potência deste Outro". (RANCIÈRE, 2004, p.61)
\end{abstract}

LYOTARD se separa de seus predecessores ao definir a potência do sublime como a potência do sensível, opondo à arte do belo - que impõe uma forma a uma matéria - uma arte do sublime, cujo trabalho é o de se aproximar da matéria, de "se aproximar da presença sem recorrer aos meios da representação" 
(LYOTARD, citado por RANCIÈRE, p.122). Trata-se então de estabelecer um novo vínculo com a matéria sensível reconhecendo sua alteridade... uma alteridade cujos traços essenciais seriam a pura diferença na qual consiste a matéria e sua possibilidade de "desamparar o espírito".

\section{6. "Relações de objeto a objeto..."}

"Estabelecer um novo vínculo com a matéria sensível reconhecendo sua alteridade": é neste ponto de encontro entre as reflexões de RANCIÈRE e LYOTARD que reconheço também os propósitos da antropologia do centro, ou a antropologia simétrica de Bruno LATOUR, esta antropologia que se interessa pelos 'vínculos' existentes dentro dessa "multidão de tudo o que faz agir" e não apenas pelos indivíduos e suas sociedades. E é também sobre este terreno que me interessa tratar parcialmente da obra do compositor francês Pierre Boulez que há décadas vem manifestando dúvidas sobre este terreno turvo da criação artística. Este compositor e também teórico da música, totalmente inserido no contexto das produções musicais de salas de concerto europeias e norteamericanas, caminhou para um certo caso-limite no que diz respeito à sua noção de obra, mas mais ainda: sobre a possibilidade mesma de considerar a criação musical. Já há alguns anos que os frequentadores da Paul Sacher Stiftung - uma fundação suíça onde seus manuscritos fermentam ao lado daqueles de Webern e Strawinski, dentro de abrigos antiatômicos, às margens do Reno, na Basiléia enquanto esperam novos títulos de sua pluma, assistem às visitas intempestivas do compositor, que ora vem agenciar fluxos de materiais migrantes de obras adormecidas para ampliações de obras "vivas", ora agregar cascadas instrumentais a passagens inteiras de obras antigas. Nada está jamais concluído entre suas obras e nada nelas surge de realmente inédito. Werner STRINZ, um musicólogo, que pesquisa nesta fundação, em um artigo no qual tenta acompanhar o processo de gestação e ampliação de algumas obras da juventude do compositor que intitulou "Objetos reencontrados", teceu o seguinte comentário:

\footnotetext{
"Seja em um projeto a longo termo como o Livro das Estruturas para dois pianos, seja no "renascimento" das Doze Notações na forma de uma composição para orquestra, a criação musical de Boulez parece se constituir sob o signo de uma potencialização, de uma "criação das criações". As filiações são ainda mais impressionantes porque elas se tecem à distância e se re-vinculam em momentos muito distantes da evolução técnica e estética do compositor". (STRINZ, 2006, p.46) ${ }^{3}$
}

Mais do que viver junto com os artistas de sua geração a grande passagem a vácuo configurada pela profunda crise de subjetividade dos artistas ocidentais deste período, e mais que uma fácil adesão aos encantos do automatismo criativo das experiências surrealistas, Boulez parece ter perseguido no trânsito de suas diferentes obras, um desejo de escutar e por em cena o material sonoro com toda sua capacidade de agência. Talvez estivesse ele na busca deste vínculo com a "multidão daquilo que faz agir" de LATOUR, ou de se defrontar a esta alteridade da matéria sensível que desampara o espírito, da qual fala LYOTARD. 
Por muito tempo, e creio que ainda nos dias atuais, a música deste compositor foi considerada sob o único prisma de uma abstração formal exacerbada. Algumas de suas declarações de juventude, de tom panfletário ou a exploração de uma técnica musical ainda muito nova, fez com que uma geração inteira de compositores e musicólogos o seguissem por esta via. Mas o fato que mais leva a este tipo de avaliação é o estilo mesmo do seu processo criativo, submerso em um impressionante número de projetos, esboços, rascunhos, enfim, uma profusão incalculável de planos, grades de agregados sonoros, testemunhando quiçá um desejo de ter sob a lupa todas as arestas da fabricação sonora. Mas já me precipito aqui sobre algumas considerações que devo retomar posteriormente, quando pretendo comentar esta profusão escritural do compositor.

Para pensar neste processo criativo, retomo uma passagem de ConstellationMiroir, um dos dois formantes levados ao público em 1957 que deveriam integrar um grupo de 5 formantes (ou "movimentos") pertencentes ao projeto inicial da Troisième Sonate para piano. O fragmento expõe uma sequência de blocos sonoros nos registros mais graves do instrumento. Na realidade, ele vem pontuar uma trama dramática, construída no decorrer desse formante. A trama consiste na gravitação de seções de sons com grande densidade - denominadas pelo compositor como "Blocos" - em regiões cada vez mais opostas e extremas no registro, em torno de uma zona estável, situada no registro médio, caracterizada por sons de pequena densidade, e por ele denominada "Pontos". Este fragmento se estende pelos 3 folhetos - G, H e I - da partitura, que podem, de acordo com as versões da execução, serem lidos como os seus 3 primeiros ou seus 3 últimos. O que chama a atenção é justamente o último bloco do fragmento, situado na extremidade do último folheto, marcando de várias formas um limite da obra: um cluster. Dez notas concentradas no registro grave pontuando um fragmento que expõe os blocos mais densos na região mais grave do piano.

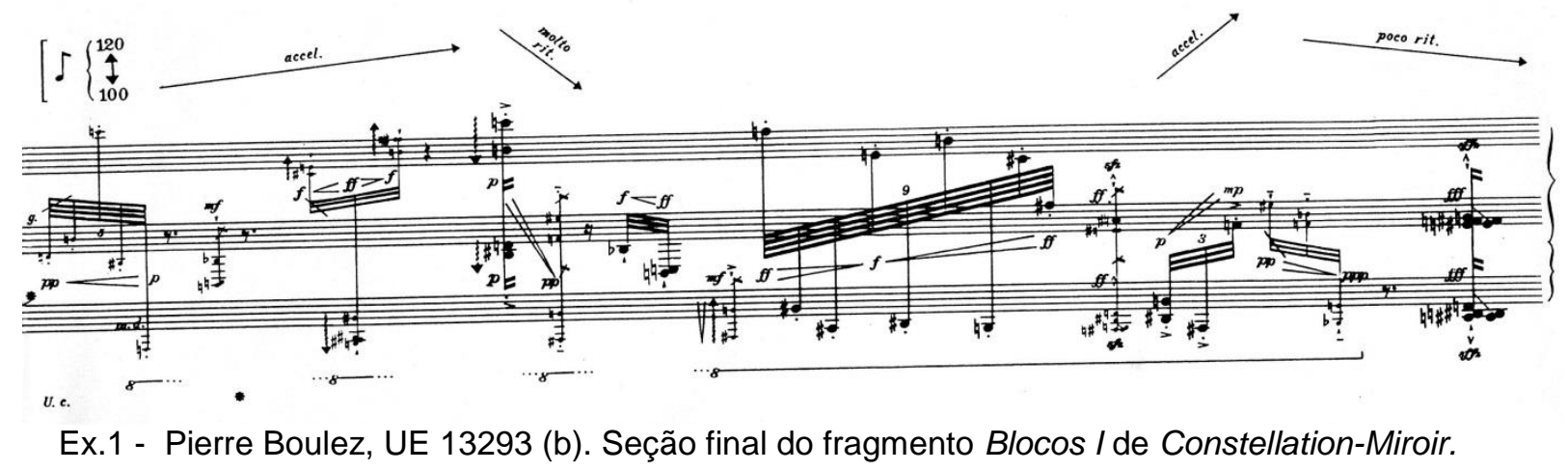

Um dos raros clusters, que podemos encontrar na obra de Boulez, ainda que aqui, na sua maneira de grafar cada nota, entendamos seu desejo de não deixálo figurar como cluster e sim como uma graduação mais intensa naquilo que ele qualificou como "complexos de sons". Esta pontuação, de uma obra destinada a uma variação de sentidos na leitura, leva ainda mais à perplexidade aqueles que estiveram atentos às suas críticas ao uso do cluster. $^{4}$

Entidades sonoras semelhantes, próximas do que tendemos a caracterizar como clusters - aparecem em outra passagem deste mesmo fragmento, constituída de 
uma trama de blocos densos, graves, atacados seca e rapidamente. São sonoridades de forte pregnância, que poderíamos considerar como ruídos mais ou menos matizados.

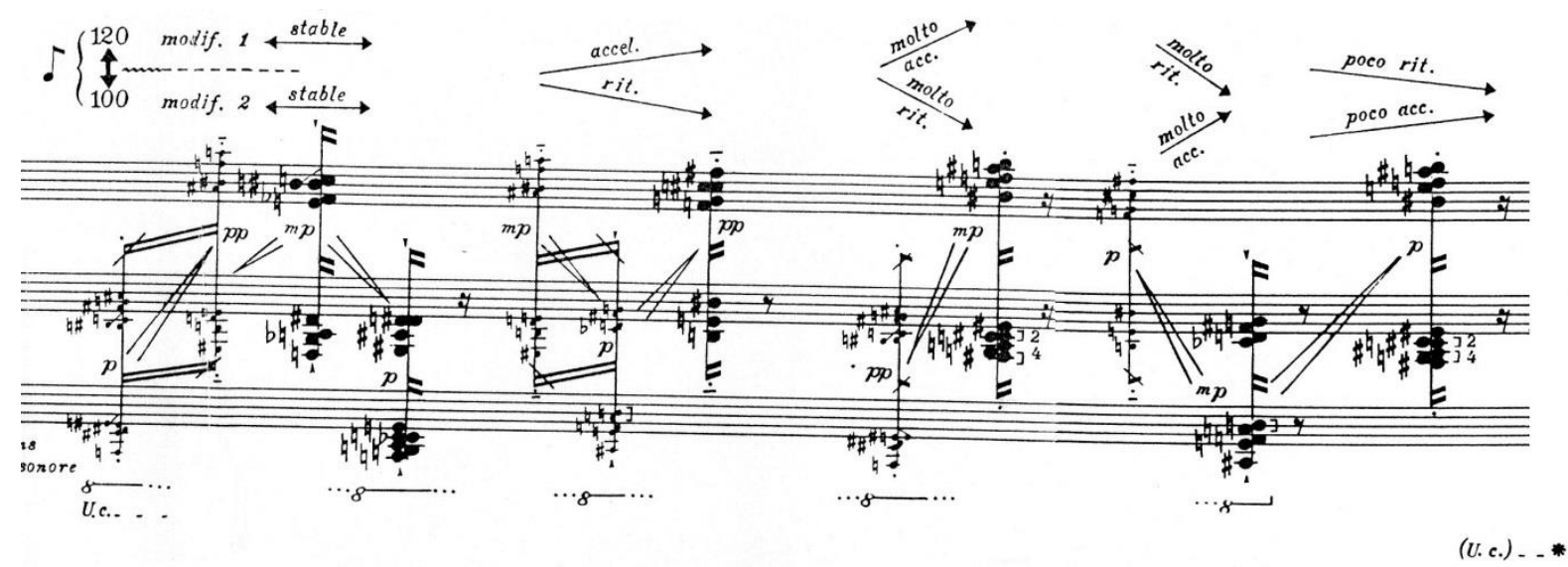

Ex.2 - Pierre Boulez, UE 13293. Seção inicial do fragmento de Blocos I de Constellation-Miroir.

Estes blocos se agrupam em 3 classes de densidades - 8, 9 e 11 sons - dentro das quais observam a mesma estrutura intervalar. Estão nesta passagem sujeitos a um certo número de repetições. Um longo procedimento é realizado até que o compositor chegue a compor estes blocos. 

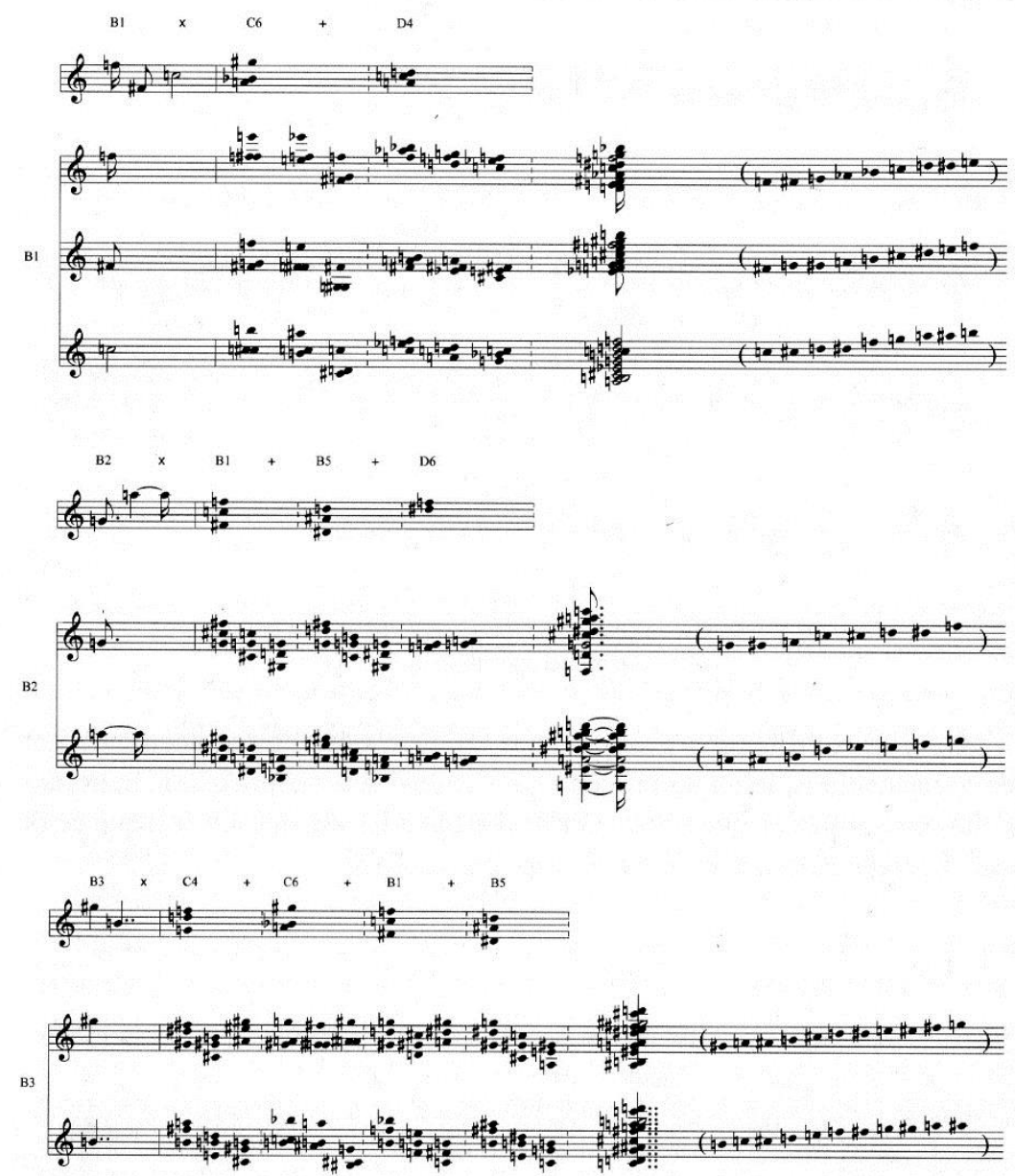

Ex.3 - Transcrição demonstrativa de um processo de ampliação dos complexos de sons utilizado por Pierre Boulez em Constellation-Miroir.

Ele repousa na leitura de redes de hierarquias criadas pela série. Na realidade, nesta composição, a série funciona como uma palheta de 6 sonoridades, com densidades variando de 1 a 3 sons, observando disposições intervalares variadas. Estas sonoridades interagem com outras, pela acumulação e pelas variações criadas nas transposições, seguindo um processo controlado pelo compositor, até que chegue à composição de blocos de grande densidade, próximos do total cromático, assim como estes que vimos. Estes blocos mais complexos, resultantes destes procedimentos já intitulados como "multiplicação de acordes" são verdadeiras amplificações das sonoridades iniciais pertencentes às diferentes formas seriais.

A independência destes blocos com respeito a uma distribuição de registros fixada a priori e a recusa a se deixar recuperar pelo princípio de identidade próprio do sistema de transposições é uma das características mais importantes da estética de Boulez. Cada objeto sonoro - e aqui neste caso, o bloco amplificado - é dotado de uma única disposição na tessitura, a única que anima e se torna responsável de sua função real. Sua figuração e disposição na tessitura revelam funções e relações entre as sonoridades. Estas não são dadas e sim 
agenciadas. Não existe um dado estrutural que encerre propriedades dos sons antes daquilo que Debussy teria chamado de mise en place sonore. Para reforçar a importância deste dado no processo de composição, proponho que imaginemos um outro caminho: estes blocos, uma vez que pertencem a uma mesma classe de densidades e possuem a mesma estrutura intervalar - tendo sido criados a partir dos mesmos princípios de interação - poderiam seguir um esquema de apresentação uniforme e mecânico, oferecendo a mesma disposição, a mesma extensão dentro do registro. Assim, a forma estaria correspondendo à estrutura. As estruturas seriam mais facilmente percebidas pelo ouvinte e 0 intérprete. $O$ que obteríamos assim seriam simples transposições:
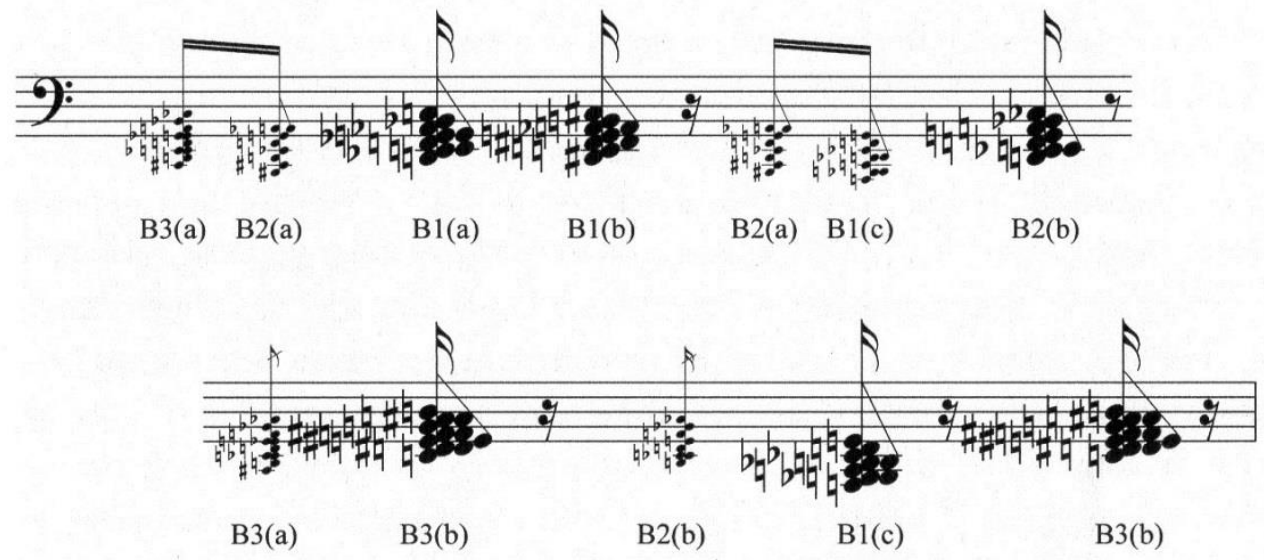

Ex.4 - Exemplo de uma disposição uniformizada dos blocos do fragmento de Constellation-Miroir de Pierre Boulez.

Mas, ao contrário: a disposição de blocos de uma mesma densidade pertencendo a uma mesma classe, bem como a forma como eles são replicados na seção, varia a cada instante. Um esboço de Boulez demonstra como o tipo de figuração que os blocos assumem nas seções é determinado pelas propriedades acústicas exploradas no instrumento. 


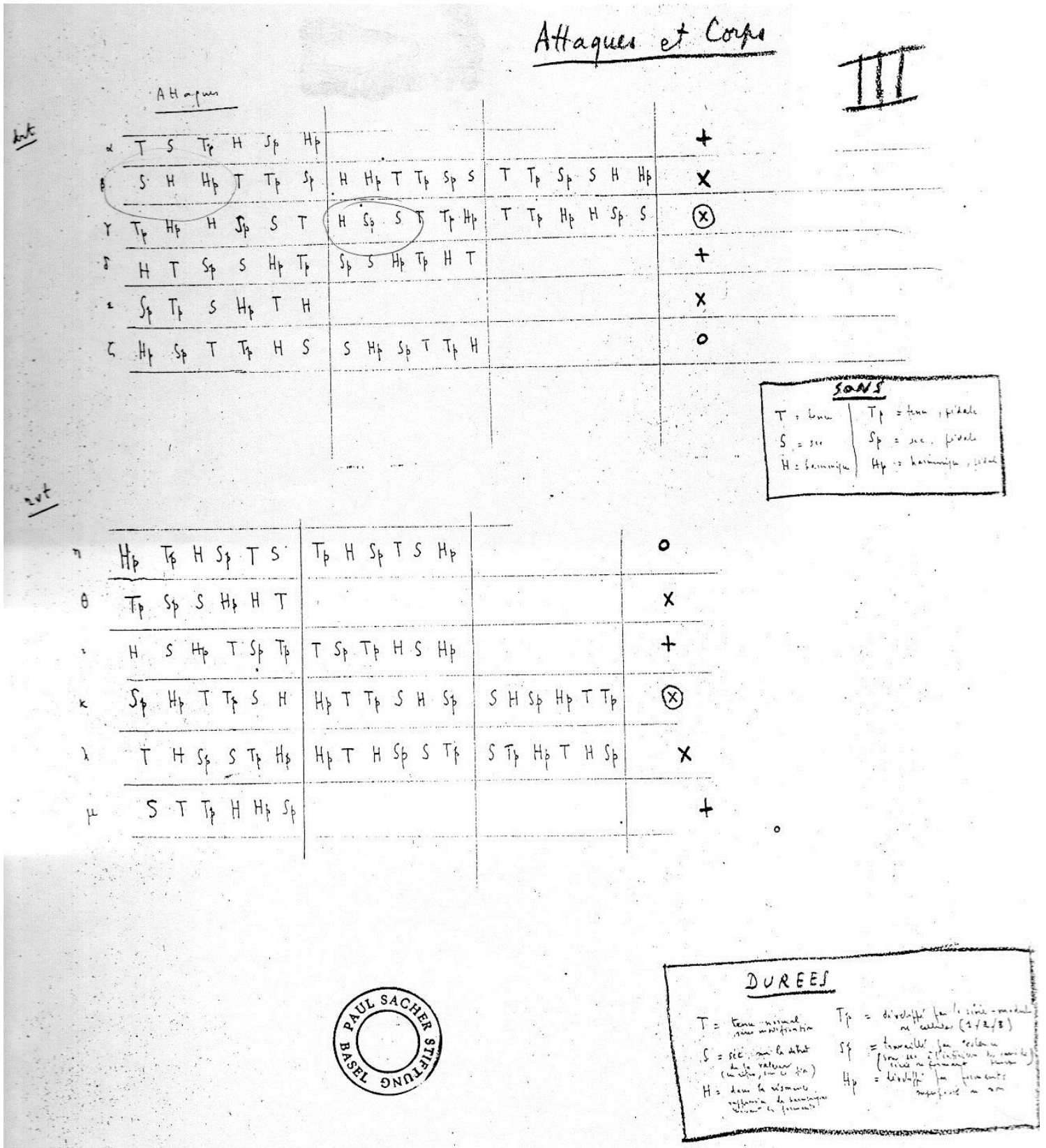

Ex.5 - Fragmento de manuscrito de Constellation-Miroir de Pierre Boulez. (Paul Sacher Stiftung, Microfilme 138 - 0827. Mapa H. Dossier 2d).

Os fragmentos se repartem em seções cujo envelope acústico se define de acordo com propriedades aqui descritas: "ataques secos", "uso de ressonâncias de harmônicos produzidas pela liberação de cordas graves", "usos de harmônicos com variações dos pedais", "tenutos", "tenutos com uso de pedais", etc. Assim, a passagem de blocos totalmente verticalizados, atacados seca e rapidamente se contrasta com a precedente em que eles se estendem em arabescos e grandes momentos de suspensão que possibilitam a escuta das ressonâncias. 


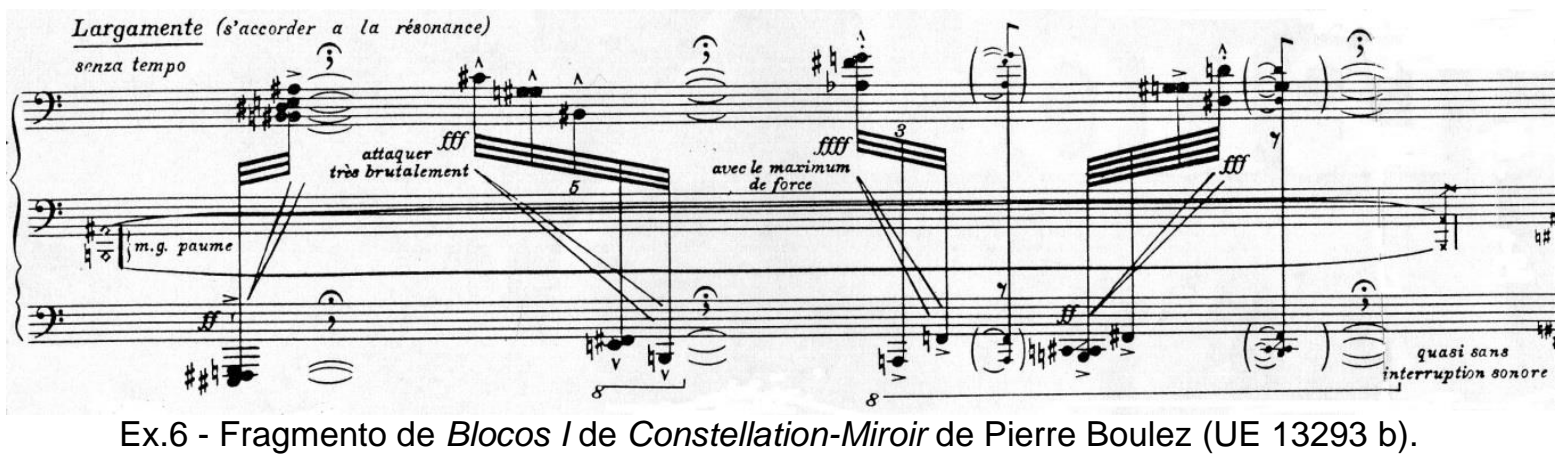

Desta forma, a matéria sonora está se expressando e agindo, não em função de uma estrutura predeterminada, intervalar, serial, como muitos acreditam. Ela se exprime a partir daquilo que o compositor passou a denominar como "deduções localizadas e variáveis", uma forma radical de negar o princípio de identidade por transposição próprio da música tonal. A este respeito, e para melhor demonstrar o que tento aqui colocar, evocaria outra passagem do mesmo formante Constellation-Miroir, extraído da seção intitulada Blocos I. Os blocos iniciais empregados nesta seção possuem estrutura semelhante àqueles que vimos na seção precedente, próximos ao cluster, se consideramos as suas alturas e densidades dentro de um espaço reduzido de uma oitava.

35
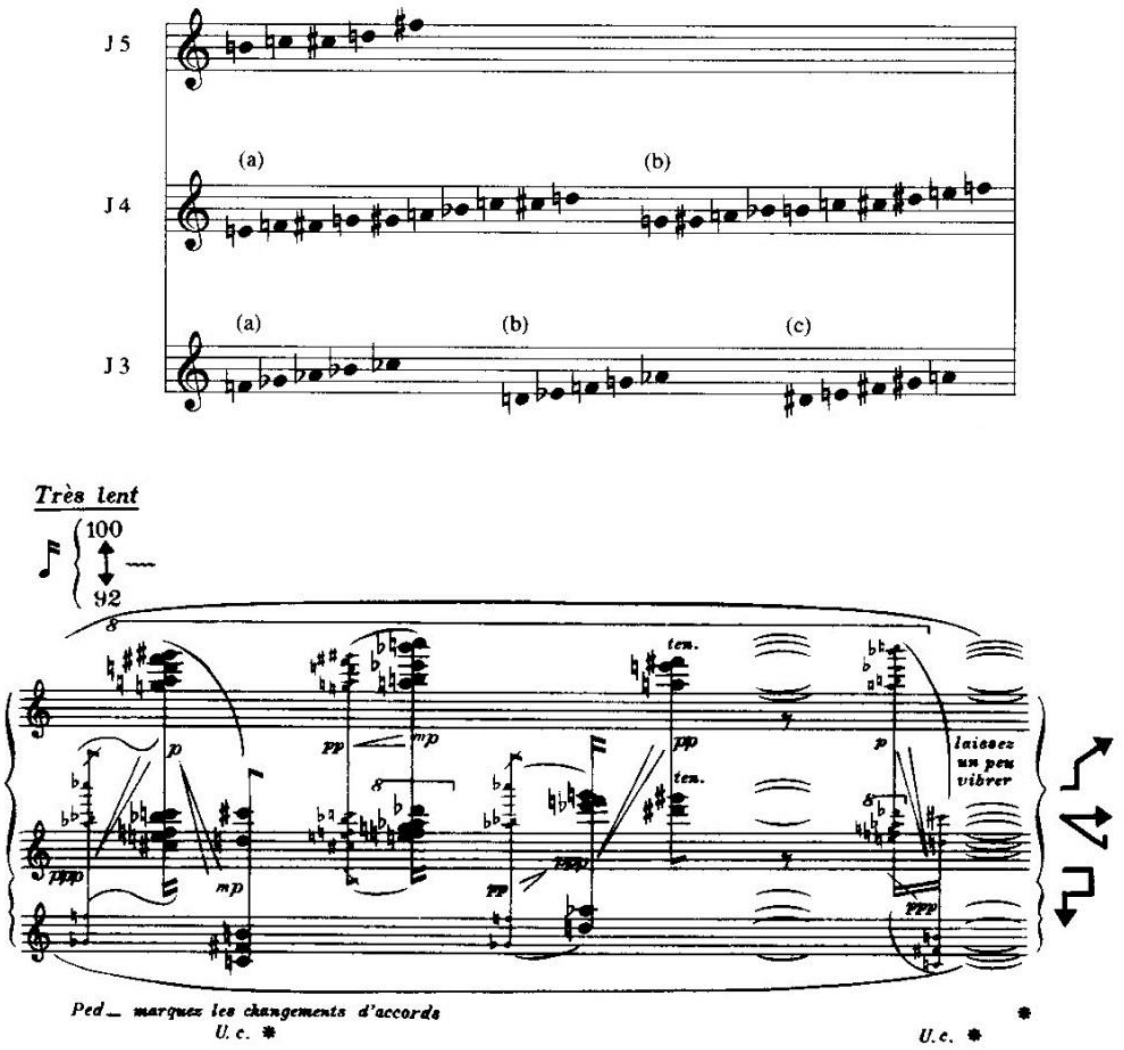

Ex.7 - Pierre Boulez. Fragmento da seção Blocos I de Constellation-Miroir (UE 13293 b) e composição dos complexos de sons. 
No entanto, ainda que aqui estejam totalmente verticalizados, a disposição aberta pela qual se estendem no registro agudo do piano e a qualidade temporal "muito lenta" conferem a estes blocos propriedades musicais totalmente diferentes daquelas dos blocos da seção precedente. Antes estávamos em uma zona de ruídos matizados, o piano ocupando função de instrumento de percussão. Aqui, estamos em uma zona de sonoridades agudas, com variações de alturas expressivas. As duas passagens precedentes ilustram este desejo do compositor em tornar ambivalentes funções e categorias do material sonoro, cuja tendência é tomá-las como definidas antes mesmo da mise en place. Esta atitude se demonstra no que diz respeito ao tema do "ruído", tão importante no contexto da criação musical dos anos 50 e 60, cujas implicações na escuta construída pelos compositores ocidentais das músicas de povos tradicionais africanos, orientais e americanos foram significativas. Acredito que o que Boulez busca nesta experiência, que, aliás, havia já se realizado em Marteau sans Maître, é extirpar os sons, antes pensados como "ruídos" de um contexto que o define como pura matéria, inerte - porque por demais pregnante - sem propriedades ativas e expressivas - porque não inseridas na lógica de identificação e transposição do sistema musical ocidental - levando-os a se vincularem às demais sonoridades da obra em constante estado de mutabilidade, de agregação e diluição. E o faz justamente porque conduz todos os seus materiais sonoros a um "ponto-precário, onde a responsabilidade das estruturas e a personalidade dos objetos se equilibram", segundo suas palavras (BOULEZ, 1974, p.45). É neste "pontoprecário" onde os objetos sonoros se encontram e se revelam, que se realizam as deduções localizadas e variáveis. Podemos assim compreender os termos em que o compositor formula suas reflexões sobre o uso destes objetos-estruturas sonoros, recusando congelá-los em definições estanques de ruído e som, propondo os termos "complexos de sons" e "sons complexos" para demonstrar a continuidade entre o que antes se definia em zonas:

\begin{abstract}
"Com esse propósito, abrirei um parênteses sobre as relações que ruído e som mantêm entre si. É certo que a hierarquia, na qual viveu o Ocidente até agora, praticamente exclui o ruído de seus conceitos formais; a utilização que dele se faz depende naturalmente de um desejo de ilustração "paramusical", descritiva. Não vejamos aí uma coincidência ou uma simples questão de gosto: a música do Ocidente recusou, durante muito tempo, o ruído porque sua hierarquia repousava no princípio da identidade das relações sonoras transponíveis para todos os graus de uma dada escala; sendo o ruído não diretamente redutível a um outro ruído, é, pois, rejeitado como contraditório ao sistema. Agora que temos um organismo como a série, cuja hierarquia não está mais fundada no princípio de identidade por transposição, mas, ao contrário, em deduções localizadas e variáveis, o ruído se integra mais logicamente a uma construção formal, contanto que as estruturas por ele responsáveis, se fundem em critérios próprios. Eles não são, fundamentalmente, diferentes - acusticamente falando - dos critérios de um som."(BOULEZ 1974 [1972])
\end{abstract}

O que me interessa não é reanimar aqui as discussões apaixonantes em torno do tema do ruído que afloraram nos anos 50 e 60, da forma como Boulez se demarcou de outros compositores a este respeito, e nem falar dos diversos 
projetos de obras para percussão iniciados por ele e não concluídos, do particular uso que ele fez de um vasto conjunto de instrumentos de sons complexos em diversas de suas obras, de seu interesse por músicas não-ocidentais, de seu projeto de estudos etnomusicológicos no Camboja, embora tudo isto possa esclarecer muito do que está em jogo na discussão que apresento. Não é este o objetivo principal do texto e não poderia aqui prosseguir esta discussão com o cuidado que ela merece.

O que me parece mais importante explorar nos exemplos que apresentei é o quanto um procedimento que Boulez denominou "deduções localizadas e variáveis" - o que parece ser um detalhe técnico em seu método composicional pode revelar todo o problema da autoria da obra que venho tentando problematizar neste texto. Por este fundamento, a composição musical se revela apenas no instante em que se vinculam e interagem as várias propriedades ativas da matéria sensível. Não há uma propriedade sonora que adquira uma função pré-determinada no processo criativo, passível de agir sobre as demais. Todas as propriedades estão sujeitas a se revelarem a partir de instantes, de cruzamentos, na interação com outras propriedades encontradas. Neste sentido, não existe no processo de composição de Pierre Boulez nenhuma noção musical imutável. Não existe propriamente uma repartição entre o material sonoro e o processo de agência ou estruturação. A noção bouleziana de deduções localizadas e variáveis é o que faz com que a produção material na obra seja incessante, já que não há um instante do processo de composição em que a estrutura se separe da força, ou o material se separe da forma. Há sempre uma dedução, um ponto de encontro, que faz com que a força do material revele novas propriedades e cause novos desvios, novas dobras, e incontáveis retornos. A composição da obra passa a ser o trabalho desta sensibilidade ativa do material sempre em expansão.

Seria então o momento de evocar novamente a reflexão sobre a razão de tal procedimento de escritura, cujo resultado, - no que diz respeito à obtenção destes blocos de sonoridades por um procedimento pontual de acumulação de notas - poderia a priori ser obtido empiricamente. Na realidade, esta formulação já é sintomática de um determinado modo de pensar a música, não como uma complexa cadeia de interações, mas como um resultado sonoro, impresso em partituras, gravações ou apresentados em concertos. A obra musical neste caso é pensada como um dado objetificável, um resultado. O que proponho, após alguns anos de imersão em estudos etnomusicológicos, é pensar já um ritual da escritura em Boulez como um ritual musical. Na realidade a escrita, ou a escritura, se a tomamos nos termos de DERRIDA (1997) não é um processo exterior ou posterior ao desejo de um suposto ente, a expressão da sua imaginação e uma instância exterior à sua corporalidade. Ao contrário: a escrita é um ritual onde 0 corpo se inscreve, imprime seus traços. Seguindo as reflexões de DERRIDA, a escrita ocidental, foi condenada, culpabilizada, nos textos de ROUSSEAU e posteriormente de LÉVI-STRAUSS, por se constituir em um suplemento que pressupõe e anula uma originalidade de um agente pensante. Se propomos a escrita como uma instância, pensada como ritual, é porque neste caso, ela não é o instrumento de um pensamento lógico racional, ela é um terreno de concertação 
entre várias vozes, apagando o sujeito humano como único agente do processo criativo. É com base nesta premissa que sugiro que Pierre Boulez, no terreno da escrita, está ritualizando, se colocando no meio de um fluxo de possibilidades, da interação de vários objetos-sujeitos, onde qualquer ponto de junção pode dar nascimento a novos materiais, novas estruturas e novas obras.

\section{7. "Eis a criança de uma noite da Iduméia..."}

Constellation-Miroir marcou talvez esse passo vertiginoso pelo qual Boulez descobre um modo de se relacionar com o objeto sonoro, deixando marcas na inauguração de uma forma a percursos variáveis, e suspendendo para sempre qualquer possibilidade de conclusão de suas obras. Sob vários aspectos 0 compositor percebe ecos de alguns dados desta experiência ao contato que teve com a publicação dos manuscritos do Livro de Stéphane Mallarmé par Jacques SCHÉRER (1954). Um Livro que nunca poderia ser lido, segundo os desejos deixados escritos pelo autor, se não fosse em situação ritualizada. Um Livro cuja escritura e cuja leitura era ela própria o seu ritual. Mas, parece-me ainda mais significativa a escolha do ciclo de poemas sob o título de Pli selon pli, retrato de Mallarmé, para o qual Boulez retira poemas situados em um largo período dentre as obras do poeta, ordenados cronologicamente do "nascimento" (Don du poème) à "morte" (Tombeau) ${ }^{6}$. Todos eles, gravitando em torno dos conceitos da "mimeses", da "produção" e da "escritura". O primeiro verso de Mallarmé de Don du poème que abre o ciclo aparece então como um empréstimo tomado por Boulez, como forma de analisar a experiência criativa com Constellation-Miroir, da qual estava apenas saindo: "Eis a criança de uma noite da Iduméia". Segundo os responsáveis da edição de obras de MALLARMÉ estabelecida pela coleção Pléiades:

\footnotetext{
"Iduméia é o país de Edom, de Esaú, o filho mais velho deserdado a favor de Jacó, o mais velho, descabelado e monstruoso. "Para a cabala judaica", continua Denis Saurat, Deus havia primeiramente criado uma humanidade monstruosa. Ela a substituiu pela humanidade atual. Jacó substituiu Isaú: homens pré-adâmicos, reis da Iduméia". Eram seres sem sexo, que se reproduziam sem mulheres, e não hermafroditas à imagem de Deus... $\mathrm{O}$ poeta faz seu poema só, sem mulher, como um rei da Iduméia, monstruoso nascimento. Este monstro será humanizado se a mulher 0 acolhe, 0 alimenta com seu leite." (notas de Henri MONDOR e G. JEAN-AUBRY in Mallarmé, 1945, p.1439) ${ }^{7}$
}

Reprodução sem debate sexual, protozoária, caótica. Multiplicação desordenada, sem aliança. O poema traduz e denuncia o confinamento, a solidão que demanda a criação do poeta e a monstruosidade da obra - a criança - única alteridade que acompanha o artista. Uma criança que nasce de um mundo esvaziado de alteridades, onde a experiência poética surge como única presença, ela nasce como pura diferença. O texto de Mallarmé assumiria aqui uma função de paráfrase analítica do que parecia se configurar na experiência de Pierre Boulez. O compositor adentra um universo em que seus diversos objetos sonoros se 
animam, falam por si, se reproduzem. Boulez compõe a partir de uma escuta à sensibilidade ativa do material, criando vínculos entre suas qualidades sensíveis, e por isto esvai-se pouco a pouco sua autoimagem enquanto autor. Mas por outro lado, sua obra é fruto de uma noite de dramática solidão. Noite sem aliança. Como estar vinculado a "uma multidão que faz agir", como parece ser o limite, a borda aonde seu procedimento criativo o levou, e ao mesmo tempo criar meio a uma irreparável solidão? Entendo aí um ponto de tensão, de suspensão, próximo ao paradoxo exposto acima por RANCIÈRE: por um lado, a força corrosiva de sua experiência musical sobre uma modalidade de escuta que deveria aproximá-lo de uma forma de sociabilidade onde o homem não é o único a modificar o espaço, os objetos, a paisagem sonora, por outro, o confinamento no qual ele permanece, como artista ocidental, a produzir suas obras, destiná-las às salas de concerto, aos parques de circulação da obra artística.

Cabe agora um parêntesis sobre o uso do termo "objeto sonoro" no título deste texto. Embora tenha uma forte conotação histórica, sobretudo a partir dos textos de Pierre Schaffer, meu intuito aqui era pensar, não em algum material definido um agregado sonoro, um tema musical, um motivo, um acorde, um timbre instrumental, um som captado em gravadores e pensá-los com ou sem o pressuposto de uma cultura que o interprete. O termo objeto apenas vem se opor a sujeito. E se opõe estrategicamente até quando ele não se encerra mais em uma estrutura, em um conjunto material constituído antes da composição, dotado de funções e força pré-definidos. Da mesma forma, tomo emprestada a noção de "agência" de Alfred GELL (1998), para o qual os objetos podem ser pensados como pessoas, por terem capacidade de mediar relações entre sujeitos. Capacidade que não é inata, estanque, pré-determinada, e sim relacional. O título que escolhi vem para se entregar a um sacrifício, já que a "agência" de um objeto, como venho formulando aqui, é algo paradoxal: se objetos possuem agência, deixam de ser objetos ou, podemos também pensar de forma inversa: artistacompositor e objetos sonoros se tornam assim todos objetos. Aqui a composição se transfere para a escuta.

Cabe mais uma observação a estas discussões: se no processo de composição de Boulez o objeto resiste a ser objeto, pois invade a estrutura até o último momento, até a dedução mais localizada, apagando assim o limite entre o objeto e o sujeito da constituição da obra, esta sua experiência não se assemelha aos jogos e cenários de azar construídos por alguns de seus colegas e artistas contemporâneos. Alguns textos de Pierre Boulez, certos deles de circulação mais marginal, poderiam compor este comentário que pretendo realizar aqui. Por um lado, exprimem esta noção que intitulo aqui como "agência dos objetos sonoros". Não é por acaso que, no ano mesmo da conclusão de Constellation-Miroir, ele tenha escrito seu belo texto sobre Debussy, onde propõe que, na forma de organização dos sons por este compositor as relações de objeto a objeto se estabelecem no contexto segundo funções não constantes.

"Foi preciso que o fato Debussy, incomensurável com qualquer academismo, incompatível com qualquer ordem não vivida, com qualquer 
regulamento que não fosse fruto do momento, permanecesse um corpo estranho à música do ocidente para que ela ficasse tão impermeável em seus desenvolvimentos posteriores: um verdadeiro banho de mercúrio. Vêse claramente o que provocou esse isolamento: Debussy recusa toda hierarquia que não esteja implicada no instante musical. Com ele, muitas vezes, o tempo musical muda de significação, sobretudo em suas últimas obras. Assim, criar sua técnica, criar seu vocabulário, criar sua forma, levaram-no a alterar profundamente noções que, até ele, tinham permanecido estáticas: o movimento, o instante fazem irrupção na música; não apenas a impressão do instante, do fugitivo, a que o reduziram; mas sim uma concepção irreversível, própria do tempo musical, e do universo musical de um modo geral. É que na organização dos sons essa concepção se traduz pela recusa das hierarquias harmônicas existentes como dados únicos dos fatos sonoros; as relações de objeto a objeto se estabelecem no contexto segundo funções não constantes." (BOULEZ 1966) ${ }^{8}$

Por outro lado, encontramos noções mais ou menos explícitas quanto à dissolução da autoria. Já o título de um dos textos publicados a respeito da Terceira Sonata em Points de repères - "Sonate, que me veux-tu?" ("Sonata, o que queres de mim?") revela muito sobre essa inversão entre os papéis de agente a paciente, sujeito e objeto do processo de composição. As últimas frases deste texto dizem em todas as letras:

\begin{abstract}
"Ainda uma palavra: a forma adquire sua autonomia, tende em direção de um absoluto que jamais conheceu; rejeita a intrusão de qualquer acidente pessoal. As grandes obras às quais me referi - Mallarmé, Joyce constituem dados de uma época: o texto se torna "anônimo" por assim dizer, "falando por ele mesmo, sem a voz do autor". Se fosse necessário encontrar um sentido profundo para esta obra que tentei escrever, seria a procura deste "anonimato"." (BOULEZ, 1981, p.163).
\end{abstract}

Em outro texto, intitulado "Musique traditionnelle - un paradis perdu?", BOULEZ evoca uma imagem - a de viver em um plasma criativo - onde podemos entender esta diluição de fronteiras entre ele e os objetos de sua criação:

\begin{abstract}
"Com respeito à noção temporal diferente, de obras cíclicas sem começo e nem fim - na Índia ou no Japão a música se escuta, se abandona, dentro de uma duração diversa da nossa - posso também dizer que no plano da criação, vivo numa espécie de plasma criativo, que me permite me deslocar, escorregando de frente para trás. Permaneço em uma só coisa e irradio em muitas direções ao mesmo tempo. Possuo agora um material maleável que me permite estes deslizes no tempo e estas recreações. É assim que já fiz muitas versões de "Pli selon pli e penso a uma ampliação de "Éclat"." $(\text { BOULEZ, 1967, p.8) })^{9}$
\end{abstract}

\begin{abstract}
"Relação de objeto a objeto", "plasma criativo", "um texto sem voz do autor", "busca do anonimato": temos aqui vários pontos de abertura para retornarmos aos problemas colocados no início deste texto. Mas não na forma de alguma resposta. Não calculei logicamente que uma crítica genética sobre experiências boulezianas pudesse me responder algo da questão que coloquei sobre a origem não autoral dos cantos entre os povos indígenas. O que a antropologia deve fazer, evocando aqui os termos de VIVEIROS DE CASTRO é
\end{abstract}




\begin{abstract}
"colocar em relação problemas diferentes, não um problema único ('natural') e suas diferentes soluções ('culturais'). A "arte da antropologia"(...) é a arte de determinar os problemas postos por cada cultura, não a de achar soluções para os problemas postos pela nossa" (VIVEIROS DE CASTRO, 2002 b., p.117).
\end{abstract}

Tampouco buscava aqui uma equação de semelhança, um ponto de encontro entre as naturezas de atividades que se passam no sonho do xamã e na noite da Iduméia de Boulez e Mallarmé. A noite da Iduméia, onde se passa a criação do poeta-músico ocidental permanece este gesto de uma "política da forma resistente", da obra autônoma, auto-contemplativa cara a Adorno. Sua evocação surge nos versos postos em música por Boulez como um grito de asfixia de um artista cujo mundo está já esvaziado de alteridades. A humanidade e os seus híbridos (LATOUR 1994) formariam a única geração de remanescentes que podem comparecer a esta aventura musical. "Anular este suspense estético" e dissolvê-lo na própria vida seria novamente cair em um mundo esquadrinhado, repartido, não qualitativo, sem vínculos, como sucedeu aos artistas da Bauhaus. De nada serve a Boulez ter desenvolvido a escuta de sujeitos sonoros, ter sonhado vincular-se à multidão que faz agir, se - flecha solitária, como ele escreveu certa vez a respeito de Debussy -, nasceu, vive, compõe e dirige suas obras nessa sociedade demasiado humana como foi acusada por Nietzsche. Impossível sonhar com a escuta de seus sujeitos musicais, se os humanos são de fato os que tomaram o poder de todo espaço, eles e seus híbridos, e cortaram seus vínculos com tudo o que faz agir.

A ópera nasceu em um dos momentos mais intensos de afirmação do humanocentrismo. Consiste na nostalgia do sátiro-pastor (a natureza), na dúvida com o invisível e na exaltação do sujeito. Todos aqueles que entrevistam Boulez, perguntam-Ihe sobre seu projeto malogrado de compor uma ópera. Ele sempre a deixou em suspense. Debussy, que tanto tardou a concluir seu Pélleas, buscava um libreto "sem país, sem datas, sem cenas a realizar... os personagens sem discutir, sujeitos à vida e ao destino" ${ }^{10}$. Com o primeiro verso de Mallarmé, Boulez compôs e abortou toda a sua ópera, exprimindo o cruel paradoxo de um artista ocidental que quisera transformar-se em ouvinte. Exprimiria ao mesmo tempo toda a impossibilidade de se colaborar hoje em um projeto artístico, autoral, ocidental, e milionário, sobre a Amazônia.

\footnotetext{
${ }^{1}$ Este texto foi escrito a partir de um seminário apresentado na Escola de Música da UFMG. Agradeço aos colegas Rogério Vasconcelos e André Cavazotti pelo apoio na leitura e revisão do texto e pela tradução do resumo.

2 Dentre várias narrativas expressas pelos povos indígenas, retomo aqui uma reflexão minha sobre um mito tikmũ'ũn do dilúvio ocasionado pelo cunhado do pai adotivo da lontra: "Após um 
grande dilúvio enviado pela ira de uma lontra, filha adotiva de um casal, um homem sobrevivente tentou de várias formas se procriar. Quando enfim nasceram os primeiros filhos na forma humana, Topa trouxe a eles um arco e flecha e uma arma de fogo. A escolha das armas deu origem à diferenciação entre os Tikmũ'ũn e os que eles chamam de "ãyuhũk", uma classe de pessoas que traduzimos como os "brancos". Acredito que a diferenciação já estava presente nessa história antes do dilúvio: entre o pai adotivo da lontra e seu cunhado. O pai adotivo, recebia fartos peixes de sua filha lontra, e em troca, deixava a ela os melhores e maiores peixes. O cunhado, pediu a lontra emprestada para receber da mesma forma tantos peixes, mas tentou enganá-la, escondendo para si os melhores. Não seria a diferença dos procedimentos entre o pai adotivo e seu cunhado a mesma que observamos entre a "economia sustentável" praticada milenarmente pelos povos indígenas, essencialmente relacional, e a exploração absoluta pela "insaciabilidade infinita do desejo humano perante os meios materiais finitos de satisfazê-los", como certa vez escreveu Eduardo Viveiros de Castro, pelos homens do Progresso?" (TUGNY, 2011, p.4)

${ }^{3}$ Nossa tradução.

4 "Até agora só considerei os complexos de intervalos simples; para ser completo, preciso assinalar a integração destes mesmos intervalos. Este método nos dá, por assim dizer, "superfícies" sonoras que utilizam, seja verdadeiramente o continuum, seja uma aproximação bastante grosseira, aliás - deste continuum pela aglomeração de todos os intervalos unitários compreendidos entre os limites dados; o que chamamos clusters no sentido vertical ou glissandi no sentido diagonal. Estudaremos mais adiante como essa idéia primitiva e excessivamente sumária está longe de uma concepção elaborada do continuum; dele, o que retém-se aqui, é apenas a sua aparência mais superficial" (BOULEZ, 1964, p.45).

5 Citamos aqui a tradução de Reginaldo de Carvalho e Mary Amazonas Leite de Barros: $A$ Música Hoje. S.P., Ed. Perspectiva, 1972.

6 Os anos de publicação dos poemas são: Don du poème (1865), Le vierge, Le vivace et le bel aujourd'hui (1885), Une dentelle s'abolit (1887), A la nue accablante tu (1895), Tombeau (de Verlaine) (1987).

7 Nossa tradução.

8 Publicado originalmente em 1956 em La Nouvelle Revue Française, n.48. Nossa tradução.

9 Nossa tradução.

10 Léon Vallas, 1958 [1932], p.141. Debussy teria respondido ao seu professor, Albert Guiraud, quando questionado sobre seu projeto de ópera e escolha de libreto: "Celui des choses dites à demi. Deux rêves associés : voilà l'idéal. Pas de pays ni de date. Pas de scène à faire. Aucune pression sur le musicien qui parachève [...] Je rêve poèmes courts : scènes mobiles. Me f... des 3 unités. Scènes diverses par lieux et caractère ; personnages ne discutant pas ; subissant vie, sort, etc ».

\section{Referências}

BOULEZ, Pierre. Penser la musique aujourd'hui. Paris, Gonthier, 1964. Tradução brasileira: Reginaldo de Carvalho e Mary Amazonas Leite de Barros: A Música Hoje. S.P., Ed.

Perspectiva, 1972. Relevés d'apprenti. Paris: Seuil, 1966.

. Points de repère. Paris: Christian Bourgois Éditeur, Édition du Seuil, 1981. . Musiques traditionnelles - un paradis perdu?» In The World of Music Quartely Journal of the International Music Council (UNESCO). Bärenreiter, IX/2, 1967.

. Existe-t-il un conflit entre la pensée européenne et non-européenne?» Europäische

Musik zwischen Nationalismus und Exotic, (ed. Hans Oesch, Wulf Arlt \& Max Haas), Winterthur: Amadeus, 1984.

. Penser la Musique Aujourd'hui, Paris: Gallimard, rééd. coll. « Tel », 1963.

. Constellation-Miroir. Troisième Sonate pour piano. Formant 3. Universal Edition UE

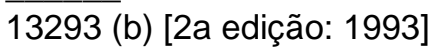


859.

(MS) Constellation (formant 3). Paul Sacher Stiftung (Basiléia) Microfilme 138 - 0810 à

DELEUZE, Gilles \& GUATTARI, Félix. L'Anti-Oedipe. Paris: Les Éditions de Minuit, 1972.

CLASTRES, Pierre. (1974). "A Sociedade contra o estado". In: A sociedade contra o estado, trad. De Theo Santiago, Cosac \& Naify, 2003.

. Mil platôs v. 4. Rio de Janeiro: Editora 34, 2005[a].

. Mil platôs v. 5. Rio de Janeiro: Editora 34, 2005[b].

Qu'est-ce que la philosophie? Paris: Les Éditions de Minuit, 1991.

DERRIDA, Jacques. [1967] Gramatologia. São Paulo: Perspectiva, 1999.

GELL, Alfred. Art and Agency: an Antropological Theory, Oxford: University Press, 1988.

LAGROU, Els. A fluidez da forma: arte, alteridade e agência em uma sociedade amazônica (Kaxinawa, Acre), Rio de Janeiro: TopBooks, 2007, 565 p.

LATOUR, Bruno. Jamais fomos modernos. Ensaio de antropologia simétrica. Tradução: Carlos Irineu da Costa. São Paulo: Editora 34 [1991], 2005.

. Reflexão sobre o culto moderno dos deuses fe(i)tiches. Bauru: Edusc, [1996], 2002.

" Factures/fractures. De la notion de réseaux à celle d'attachement ». in (André

Micoud et Michel Peroni) Ce qui nos relie, Editon de l'Aube, La Tour d'Aigues, p.189-208.

LÉVI-STRAUSS, Claude. O cru e o cozido. (tradução: Beatriz Perrone-Moisés), São Paulo:

Cosac Naify, 2004a.

2004b.

Do mel às cinzas. (tradução: Beatriz Perrone-Moisés), São Paulo: Cosac Naify, Naify, 2006.

Origem dos modos à mesa. (tradução: Beatriz Perrone-Moisés). São Paulo: Cosac

L'Homme nu, Paris: Plon, 1971.

MALLARME, Stéphane. Oeuvres complètes. (editor: Henri Mondor e G. Jean-Aubry). Paris:

Gallimard, 1945.

NIEZSCHE, Frederich. O nascimento da tragédia ou helenismo e pessimismo. Tradução de J.

Guinsburg. São Paulo: Companhia das Letras, 1992.

RANCIĖRE, Jacques. Jacques Rancière. Malaise dans l'esthétique, Paris: Galilée, 2004.

Tradução de Augustin de Tugny: Devires, Belo Horizonte, v.7, n.2, jul/dez 2010, p.4-24.

TUGNY, R. P. Le piano et les dés. Étude sur Music of Changes, Klavierstück XI et

Constellation-Miroir. Tese (Doutorado em Musica e Musicologia). Université de Tours. France, 1996.

. "Des Glissements dans le Temps". Musicorum. Tours, França, v.2, p.13 -32, 2004.

"L'autre moitié de l'art". Pierre Boulez. Techniques d'écriture et enjeux esthétiques.

Editores: Jean-Louis Leleu \& Pascal Decroupet. Genève: Éditions Contrechamps, 2006, v. 1, p. 299-317.

. "O trem do progresso" 2011. Espaço Público Periódico,

http://piseagrama.org/artigo/333/trem-do-progresso/

STRINZ, Werner. "Quelques observations sur des "Objets retrouvés" dans l'oeuvre de Pierre

Boullez ». Pierre Boulez. Techniques d'écriture et enjeux esthétiques. Editores: Jean-Louis

Leleu \& Pascal Decroupet. Genève: Éditions Contrechamps, 2006, v. 1, p p. 45-93.

SEEGER, Anthony. Why Suyá Sing. Cambridge: Cambridge University Press, 1987

SLOTERDIJK, Peter. Regras para o parque humano. (Tradução: Marques, Jose Oscar de

Almeida). São Paulo: Editora Estação Liberdade, 2000.

VALLAS, Léon. Claude Debussy et son temps. Paris: Alcan, 1932 [réedit. Albin Michel, 1958].

VIVEIROS DE CASTRO. A inconstância da alma selvagem. São Paulo: Cosac \& Naify, 2002.

. 2002b "O nativo relativo". In Mana n.8, Rio de Janeiro, p.113-148.

Rosângela Pereira de Tugny é integrante do INCT-CNPq de Inclusão Social no Ensino Superior e na Pesquisa. Graduada em música pela UFMG, possui Doutorado em Música pela Université de Tours (França) e realizou pós- 
doutorado em Antropologia Social junto ao Museu Nacional da UFRJ. É professora associada do Departamento de Teoria Geral da Música e do Programa de Pós-Graduação em Música da UFMG. Como pesquisadora do CNPq realiza pesquisas sobre os trabalhos acústicos dos povos tikmũ'ũn e sua continuidade na escrita. Coordena o projeto de Documentação de sonoridades indígenas "O trabalho da memória através dos cantos" junto ao Museu do Índio - Funai. Em colaboração com xamãs, ilustradores e narradores tikmũ'ũn, organizou dois livros de tradução de cantos e mitos de sua cultura ancestral "Cantos e histórias do morcego-espírito e do hemex" e "Cantos e histórias do gavião-espírito" e foi curadora da exposição "Cantobrilho tikmũ'ũn, no limite do país fértil" realizada pelo Museu do Índio - Funai. É autora de artigos e livros publicados no Brasil, em Portugal, na Suíça, na França e no Japão. 